\title{
A RETURN TO THE MANIFEST JUSTICE PRINCIPLE: A \\ CRITICAL EXAMINATION OF THE "REASONABLE \\ SUSPICIONIAPPREHENSION OF BIAS" AND "REAL \\ POSSIBILITY OF BIAS" TESTS FOR JUDICIAL BIAS IN SOUTH \\ AFRICA AND ENGLAND
}

ES Nwauche*

\section{Introduction}

The impartiality of judges often expressed in the Latin maxim nemo iudex in propria causa interpreted to mean that no man should be a judge in his own cause together with the right of fair hearing makes up the right to natural justice. This principle is recognised by a number of provisions of the Constitution of the Republic of South Africa 1996. Section 165(4) provides that the organs of state shall, through legislative and other measures, assist and protect the courts to ensure their independence, impartiality, dignity, accessibility and effectiveness. Furthermore, section 34 of the same Constitution provides that everyone has the right to have any dispute resolved by the application of law by a court or, where appropriate another independent and impartial tribunal or forum. Article 6(1) of the European Convention of Human Rights and Fundamental Freedoms 1950 as incorporated in the Human Rights Act 1988, applicable in England since 2000 provides that:

In the determination of his civil rights and obligations ... everyone is entitled to a fair hearing ... by an independent and impartial tribunal established by law.

The independence of courts and impartiality of judges are closely related ${ }^{1}$ in that they operate to sustain public confidence in the administration of justice.

* Visiting Professor of Law, Faculty of Law, North West University (Potchefstroom Campus) and Associate Professor of Law, Faculty of Law, Rivers State University of Science and Technology, Nkpolu, Port Harcourt, Rivers State. 
This article advocates a return to the use of the manifest justice principle enshrined in the words of Lord Hewart CJ in $R v$ Sussex Justices ex parte McCarthy ${ }^{2}$ that it is "of fundamental importance that justice should not only be done, but should manifestly and undoubtedly be seen to be done"3 as the proper context ${ }^{4}$ for the application of the tests of "reasonable apprehension of bias" adopted by South African courts ${ }^{5}$ and "real possibility of bias" adopted by English courts ${ }^{6}$ in the consideration of allegation of apparent bias. It will be argued that the tests are different ${ }^{7}$ and that while the English test is a move of English courts from the real danger/likelihood test in consonance with an overwhelming global jurisprudence, ${ }^{8}$ the South African test is a move away from this global jurisprudence and arguably back to the real danger/likelihood test. It is also argued that the reasonable apprehension test as applied by the

1 See the European Court of Human Rights in Findlay v UK 199724 EHRR 221, par 73: "... in order to establish whether a tribunal can be considered as 'independent', regard must be had inter alia to the matter of appointment of its members and their term of office, the existence of guarantees against outside pressures and the question whether the body presents an appearance of independence. As to the question of 'impartiality' there are two aspects to this requirement. First, the tribunal must be subjectively free of personal prejudice or bias. Secondly it must also be impartial from an objective viewpoint, that it must offer sufficient guarantees to exclude any legitimate doubt in this respect."

$2 \quad R$ v Sussex Justices ex parte McCarthy [1923] All ER 233. Hereafter Sussex Justices.

$3 \quad$ Ibid at $\mathrm{p} 234$.

4 See $R v$ Secretary of State for the Home Department, ex parte Daly [2001] 3 All ER 433 (HL) approved in Take and Save Trading CC v Standard Bank of SA Limited 2004 (4) SA 1 (SCA).

5 See President of the Republic of South Africa v South African Rugby Football Union (2) 1999 (4) SA 147. Hereafter SARFU 2.

6 The House of Lords in Porter $v$ Magill [2002] 1 All ER 465 (HL) (hereafter Porter) modified the real likelihood/real danger test formulated in $R v$ Gough [1993] 2 All ER 724 (HL) (hereafter Gough).

7 In $R \vee$ Bow Street Metropolitan Stipendiary Magistrate and others ex parte Pinochet Ungarte (No. 2) [1999] All ER 577 (hereafter Pinochet 2), Lord Hope comparing the "real likelihood test" - modified into the "real possibility" and "reasonable suspicion" test concluded that: "Their application by the appellate courts ... is likely in practice to lead to results which are so similar as to be indistinguishable". In Locabail (UK) Ltd v Bayfield Properties Ltd, Locabail (UK) Ltd $v$ Waldorf Investment Corp, Timmins $v$ Gromley, Willams $v$ HM Inspector of Taxes, $R$ v Bristol Betting and Gaming Licensing Committee, ex parte O'Callaghan [2000] 1 All ER 65 (hereafter Locabail) the English Court of Appeal concluded that the courts would have reached the same conclusion on the use of the two tests by concluding that in an overwhelming number of cases the results would be the same.

8 For Australia, the test is a reasonable apprehension of bias. See the case of Ebner $v$ Official Trustee in Bankruptcy (2000) 205 CLR 337. For Canada see Mackin v New Brunswick (Minister of Justice); Rice v New Brunswick (2002) 209 DLR (4 $\left.{ }^{\text {th }}\right) 564$. For the European Court of Human Rights, see Findlay v United Kingdom (1997) 24 EHRR 221. For Lesotho, see the case of Sekoati v President of the Court Martial 2001 (7) BCLR 750 (Les CA). 
minority in SACCAWU $v$ Irvin \& Johnson Ltd (Seafoods Division Fish Processing $)^{9}$ is a more acceptable interpretation of the reasonable apprehension test than the test laid down in SARFU 2 and its interpretation by the majority in SACCAWU 1. More importantly, the cases where the tests have been applied will be examined and hopefully it will be shown that there are considerable problems and inconsistencies in their application and it will be argued that the manifest justice principle provides the proper context for the tests to be properly applied. The tests for actual bias will firstly be considered and then how the two countries approach the issue of apparent bias will be examined. This procedure will be followed in order to enable a proper understanding of the arguments that will be made in this paper.

\section{The test for actual bias}

Actual bias, which is taken to mean a situation where the judicial officer is a party to a case or has pecuniary interest in the case, is approached in different ways by the two countries. The presence of actual bias in England leads to automatic disqualification of the judicial officer. The reverse is the case in South Africa, where there is a conflation of apparent and actual bias and allegations of bias are subjected to one and the same test. The situation in England will firstly be considered and then the situation in South Africa will be dealt with.

\subsection{Actual bias in England}

The overriding public interest principle that there should be confidence in the administration of justice is at the heart of the manifest justice principle. In England, this principle operates to disqualify a judge automatically when he is 
a party to or has pecuniary interest in a case. In Dimes $v$ Proprietors of the Grand Junction Canal, ${ }^{10}$ the court stated that:

$\ldots$ it is of last importance that the maxim that no man should be a judge in his own cause should be held sacred. And that is not to be confined to a cause to which he is a party, but applies to a cause in which he has an interest. ${ }^{11}$

In $R v \operatorname{Rand}^{12}$ the court also stated that:

There is no doubt that any direct pecuniary interest however small, in the subject of inquiry, does disqualify a person from acting as a judge in the matter... 13

This view is also reiterated in $R v$ Camborne Justices ex parte Pearce ${ }^{14}$ where the court stated that:

It is of course clear that any direct pecuniary or proprietary interest in the subject matter of proceeding, however small, operates as an automatic disqualification. ${ }^{15}$

In Pinochet 2, the House of Lords expanded the category of cases where automatic disqualification of a judge would occur from pecuniary to nonpecuniary interests such as where the judges' decision would lead to the promotion of a cause in which the judge was involved with one of the

10 Dimes v Proprietors of the Grand Junction Canal (1852) 3 HL Case 759.

11 At $\mathrm{p} 793$.

$12 R \vee$ Rand (1866) LR 1 QB 230.

13 Ibid at $\mathrm{p} 232$.

$14 R$ v Camborne Justices ex parte Pearce [1954] 2 ALL ER 850 (hereafter Camborne Justices).

15 Ibid at $\mathrm{p}$ 853. In Locabail, the Court of Appeal held after a review of the authorities such as BTR Industries South Africa (Pty) Ltd v Metal and Allied Workers Union 1992 (3) SA 673 (A) (hereafter BTR Industries); $R$ v Inner West London Coroner, ex parte Dallaglio [1994] 4 All ER 139, 162 (hereafter Dallaglio) and Auckland Casino Ltd v Casino Control Authority [1995] 1 NZLR 142, 148 that there is a "de minimis exception" provided that the potential effect of any decision on the judge's personal interest is so small as to be incapable of affecting his decision one way or the other. This does not seem to represent the law especially after Pinochet 2. 
parties, ${ }^{16}$ thereby dispensing with any inquiry into whether there is apparent bias. Lord Browne-Wilkinson said:

If the absolute impartiality of the judiciary is to be maintained, there must be a rule which automatically disqualifies a judge who is involved, whether personally or as a director of a company in promoting the same causes in the same organization as is a party to a suit. ${ }^{17}$

Lord Hutton also stated that:

I am of the opinion that there could be a case where the interests of the judge in the subject matter of the proceedings arising from his strong commitment to some cause or belief or his association with a person or body involved in the proceedings could shake public confidence in the administration of justice as much as shareholding 18

In this case, the extradition of the applicant, a former head of state of Chile was sought by the government of Spain so that he could be tried for various crimes against humanity allegedly committed while he was head of state. A metropolitan stipendiary magistrate issued two provisional warrants for his arrest. The applicant successfully applied to the Divisional Court to quash those warrants, but the quashing of the second warrant was stayed to enable an appeal to the House of Lords on the question of the proper interpretation and scope of the immunity of a former head of state from arrest and extradition proceedings in the United Kingdom in respect of acts committed whilst a head of state. Amnesty International (Al) was granted leave to intervene in the proceedings. The appeal was allowed by a majority of three to two and the second warrant was restored. Subsequently the applicant discovered that one of the Law Lords in the majority was a director and chairperson of Amnesty International Charity Ltd, which had been established to carry out Al's charitable purposes and petitioned the House to set its order

16 The House of Lords held that the long relationship and proximity of the relationship between Amnesty International and Lord Hoffman who was a director of Amnesty International Charity was such that he was automatically disqualified. It is interesting to note that Lord Hoffman served without remuneration.

17 N 6 p 588. 
aside. The significance of Pinochet 2 lies in the willingness of the Lords to expand the category of cases where there is no need to inquire into the existence of apparent bias on the basis of the manifest justice principle itself needed to maintain public confidence in the administration of justice.

The manifest justice principle operates in the context of the circumstances of the case and may even be invoked on the basis of a mere suspicion. In $R v$ Sussex Justices ex parte McCarthy ${ }^{19}$ the applicant came before magistrates charged with the offence of dangerous driving, which had involved a collision between his vehicle and another vehicle. The solicitor acting as a magistrate's clerk was also acting as solicitor for the other driver in the civil proceedings against the applicant arising out of the collision. At the conclusion of evidence before the magistrate, the acting clerk retired with them in case his help should be needed on a point of law; but in fact the magistrates did not consult him and he himself abstained from referring to the case. The court convicted the applicant, but a Divisional Court quashed his conviction. Lord Hewart CJ said:

It is said, and, no doubt, truly, that when the gentlemen retired in the usual way with the justices, taking with him the notes of the evidence in case the justices might desire to consult him, the justices came to a conclusion without consulting him, and that he scrupulously abstained from referring to the case in any way. But while that is so, a long line of case shows that it is not merely of some importance but is of fundamental importance that justice should not only be done, but should be manifestly and undoubtedly be seen to be done. The question therefore is not whether in this case, the deputy clerk made any observation or offered any criticism which he might not have properly made or offered; the question is whether he was so related to the case in its civil aspects as to be unfit to act as a clerk to the justices in the criminal matter. The answer to that question depends not upon what actually was done but what might appear to be done. Nothing is to be done which creates even a suspicion that there has been an improper interference with the course of justice $\ldots{ }^{20}$

18 Ibid at p 597.

$19 \mathrm{~N} 2$.

20 Ibid at $\mathrm{p}$ 233-234. This dictum has been quoted with approval by South African Courts: Liebenberg v Brakpan Liquor Licensing Board 1944 WLD 52 at 55; S v Radebe 1973 (1) 


\subsection{Actual bias in South Africa}

As stated above there is no difference between actual and apparent bias in South Africa. ${ }^{21}$ While this principle has not been the subject of judicial pronouncement it is implied in cases where such interests that would constitute actual bias in England are subjected to the test for apparent bias. ${ }^{22}$ In Rose $v$ Johannesburg Local Road Transportation Board ${ }^{23}$ a company applied for exemption certificates to the Transportation Board which controlled the issuance of exemption certificates regulating the commercial operation of self drive car-hire services. The chairman of the Board was also a director of three powerful companies, one of which was the largest operator of taxis in Johannesburg, opposed to the application which, if granted, would not have been to its benefit. The chairman was asked to recuse himself and he refused to do so. On review the court held that a reasonable man would apprehend that the chairman was biased. In Parag $v$ Ladysmith City Council ${ }^{24}$ members of a licensing appeal committee who were holders of a general dealers' licence were disqualified because their membership led to an apprehension of bias. In Peri-Urban Areas Health Board $v$ Administrator Transvaal ${ }^{25}$ the membership of a commission of inquiry to determine the extension of municipal boundaries by an engineer who was also a member of a firm of

SA 796 (A) at 811; Magqabi v Mafundityala (1979) 4 SA 106 (E) at 110; S v Herbst 1980 (3) SA 1026 (T) at 1029; S v Louw, S v Noyila 1981 (4) SA 939 (E) at 940.

21 This is also the position in Australia where the High Court in Ebner $v$ The Official Trustee in Bankruptcy [2000] HCA 63, par 33-34: "The common law in both England and Australia in relation to this subject has come a long way since the middle of the nineteenth century. In Australia, the common law has developed along lines somewhat different from the development in England. In this country, an issue such as that which arose in Pinochet (No. 2) would be resolved by asking whether a fair-minded lay observer might reasonably apprehend that the judge might not bring an impartial mind to the resolution of the question the judge was required to decide. That is the test to be applied in the present appeals. And it reflects the general principle which is to be applied to the problems of apprehended bias, whether arising from interest, conduct, association, extraneous information, or some other circumstance."

22 See Baxter Administrative Law 562 who said: "... the courts have always accepted that whenever a decision-maker has a pecuniary interest in the outcome of the decision, there is a reasonable apprehension of real likelihood of bias".

23 Rose $v$ Johannesburg Local Road Transportation Board 1947 (4) SA 272 (W).

24 Parag v Ladysmith City Council 1961 (3) SA 714 (N).

25 Peri-Urban Areas Health Board v Administrator Transvaal 1961 (3) SA 669 (T). 
consulting engineers, was held to have created an apprehension of bias because of the fact that his firm stood to benefit from the extension of the municipal boundaries. Accordingly, the member was ordered by the court to recuse himself. The facts of Liebenberg $v$ Brakpan Liquor Licensing Board ${ }^{26}$ are that the mayor of a municipality sat on the local liquor licensing board when it heard competing applications including one from the mayor's brother for a liquor licence. The licence was granted to the mayor's brother. The court held that the blood relationship was enough to create a likelihood of bias. The involvement of the wife of a judicial officer has been held to create an apprehension of bias. In $S v \mathrm{Bam}^{27}$ the wife of the magistrate was a witness of the State while in $S v S h a r p,{ }^{28}$ the wife of the magistrate was involved in the arrest of the accused person and gave evidence. In Bam-Mugwanya $v$ Minister of Finance and Provincial Expenditure, Eastern Cape ${ }^{29}$ the removal of a member of a tenders board was upheld because of her financial interests in a passenger service whose contract was being considered for extension by her board. This level of personal interest was held to be sufficient to necessitate her recusal.

The position in South Africa is such that it may not be difficult for the courts to recognise a category of automatic disqualification. Even if they do not in a formal sense, it is important that the public policy consideration of maintaining the confidence of the public in the administration of justice is at the heart of the test for judicial bias. Pinochet 2 can be said to have rekindled the manifest justice principle given that the court expanded the automatic disqualification rule to maintain public confidence in the administration of justice. It is this need to sustain the confidence of the public that drives the analysis below. The test for apparent bias in England follows.

1944 WLD 52.

S v Bam 1972 (4) SA 41 (E).

$S$ v Sharp [2002] JOL 9320 (Ck).

Bam-Mugwanya v Minister of Finance and Provincial Expenditure, Eastern Cape 20014 (SA) 120 (Ck). 


\section{The tests for apparent bias}

\subsection{The real possibility test in England}

For a long time English courts applied two tests in determining the presence of bias on the part of a judicial officer. The first test was the "real likelihood" or "real danger" of bias. In R v Barnsley County Borough Licensing Justices, ex parte Barnsley and District Licensed Victualler' Association, ${ }^{30}$ Lord Devlin stated that:

We have not to inquire what impression might be left on the minds of the present applicants or on the minds of the public generally. We have to satisfy ourselves that there was a real likelihood of bias: not merely satisfy ourselves that that was the sort of impression that might reasonably get abroad. ${ }^{31}$

The second test is the reasonable apprehension or suspicion test. In Metropolitan Properties Co (FGC) Ltd v Lannon, ${ }^{32}$ Lord Denning set out the test thus:

In considering whether there was a real likelihood of bias the court does not ... look to see if for extension there was a real likelihood that he would or did in fact favour one side at the expense of the other. The court looks at the impression which would be given to other people ... the reason is plain enough. Justice must be rooted in confidence: and confidence is destroyed when right-minded people go away thinking: 'The judge was biased'. ${ }^{33}$

In Gough the House of Lords adopted the "real danger/likelihood test". Lord Goff of Chieveley formulated the test thus:

I think it unnecessary, in formulating the appropriate test, to require that the court should look at the matter through the eyes of a reasonable man, because the court in cases such as these

$30 R$ v Barnsley County Borough Licensing Justices, ex parte Barnsley and District Licensed Victualler' Association [1960] 2 QB 167 (hereafter Barnsley Justices).

31 At pp 186-187. See also $R$ v Box [1964] 1 QB 340; $R$ v Sawyer (1980) 71 Cr App R 283; and $R$ v Spencer [1987] AC 128.

32 Metropolitan Properties v Lannon [1969] 1 QB 577 (hereafter Metropolitan Properties).

33 At $\mathrm{p}$ 599. Cf Sussex Justices [1924] 1 KB 256; $R$ v Liverpool City Justices, ex parte Topping [1983] 1 All ER 490; and R v Mulvihill [1990] 1 All ER 436. 
personifies the reasonable man; and in any event the court has first to ascertain the relevant circumstances from the available evidence, knowledge of which would not readily be available to the observer in court at the relevant time. Finally, for the avoidance of doubt, I prefer to state the test in terms of real danger rather than probability of bias. Accordingly, having ascertained the relevant circumstances the court should ask itself whether, having regard to those circumstances, there was a real danger of bias on the part of the relevant member of the tribunal in question, in the sense that he might unfairly regard (or have unfairly regard) with favour, or disfavour, the case of a party to the issue under consideration by him ... ${ }^{34}$

The test in Gough was a reaction to the trend in English law which sought to base the test of apparent bias on "mere suspicion". Thus in Camborne Justices, the court attacked the "mere suspicion" test declaring it as a

[...] warrant for quashing convictions or invalidating orders upon quite unsubstantial grounds and indeed, in some cases, upon the flimsiest pretext of bias. $^{35}$

In Barnsley Justices, Devlin LJ stressed the need to abandon the "mere suspicion" test when he stated that in assessing the allegation of bias, the court should not

[...] inquire what impression might be left in the minds of the present applicants or on the minds of the public generally. ${ }^{36}$

Lord Goff in Gough alluded to the reliance on "mere suspicion" as the basis of the test for bias as being the effect of the decision in the Sussex Justices case.

In Locabail, the Court of Appeal sought to elaborate on the content of the test of real danger/likelihood of bias. ${ }^{37}$ In the court's opinion:

See $n 6$ above at $\mathrm{p} 670$.

$\mathrm{N} 14$ above at $p 855$.

$\mathrm{N} 30$ above at $p$ 714-715.

This case is a judgment on five cases, which were applications for permission to appeal and they touched on a common question concerning the disqualification of judges on grounds of bias. See $n 7$ above. Cf Malleson 2000 Modern Law Review 119. The author believes that this case is a reaction to the uncertainty that trailed the decision in Gough. Reference is made to the dictum of Lord Woolf in Gough at p 740: "The court should 
It would be dangerous to list the factors which may or may not give rise to a real danger of bias. Everything will depend on the facts, which may include the nature of the issue to be decided. We cannot conceive of circumstances in which the objection could be soundly based on religion, ethnic or national origin, gender, age, class, means or sexual orientation of the judge. Nor, at any rate ordinarily could an objection be soundly based on the judge's social or educational or service or employment background or history, nor that of any member of the judge's family; or previous political associations; or membership of social or sporting or charitable bodies; or Masonic associations; or previous judicial decisions; or extra-curricular utterances (whether in textbooks, lectures, speeches, articles, interviews, reports or responses to consultation papers); or previous receipt of instructions to act for or against any party, solicitor or advocate engaged in a case before him; or membership of the same inn, circuit, local law society or chambers ... by contrast, a real danger of bias might well be thought to arise if there were personal friendship or animosity between the judge and any member of public involved in the case or if the judge were closely acquainted with any member of the public involved in the case, particularly if the credibility of that individual could be significant in the decision of the case; or if, in a case where the credibility of any individual were an issue to be decided by the judge, he had in a previous case rejected the evidence of that person in such outspoken terms as to throw doubt on his ability to approach such person's evidence with an open mind on any later occasion; or if on any question at issue before him the judge had expressed, particularly in the course of the hearing, in such extreme and unbalanced terms as to throw doubt on his ability to try the issue with an objective judicial mind ... or if, for any other reason, there was real ground for doubting the ability of the judge to ignore extraneous considerations, prejudices and predilections and bring an objective judgment to bear on the issues before him. The mere fact that a judge, earlier in the same case or in a previous case, had commented adversely on a party or witness or found the evidence of a party or witness to be unreliable, would not without more found a sustainable objection ... We repeat: every application must be decided on the facts and circumstances of the individual case. The greater the passage of time between the event relied on as showing a danger of bias and the case in which the objection is raised, the weaker (other things being equal) the objection would be. ${ }^{38}$

In two of the cases that make up Locabail: Locabail (UK) Ltd $v$ Bayfield

Properties Ltd and Locabail (UK) Ltd $v$ Waldorf Investment Corporation, the

hesitate long before creating any other special category since this will immediately create uncertainty as to what are the parameters of that category and what is the test to be applied in that case of that category".

38 At $\mathrm{p} 78$. 
court in applying the real danger test declined to accept that the discovery of a conflict of interest, which under the Law Society's conflict rules, would disqualify a solicitor from acting for one or the other of the parties to a case necessarily bars the solicitor from hearing the case as a deputy judge or requires a hearing already started to be aborted or a judgment given on the case to be set aside. Everything, the court argued, depended on the circumstances of the case. The fact that the solicitor had only known of the involvement of his firm in the course of the trial and had made this known to the parties the next day and the declaration that he knew nothing of his firm's involvement was instrumental. The court seemed unduly influenced by the question of actual bias. That can be the only explanation for the reliance it placed on the solicitor's declaration of lack of knowledge of the matter his firm was handling and the fact that given the large size of the firm - 145 solicitors and over 300 assistant solicitors - the solicitor was telling the truth. With due respect, the court misapplied the rule in Gough. The court should not have laboured to assess proof of actual bias. It should have determined what a reasonable onlooker objectively viewing the proceedings would feel about the solicitor whose professional association would not approve of his representing one of the parties sitting in judgment over the parties. In Timmins $v$ Gormley, the allegation of apparent bias was the intellectual bent of the judge. It was alleged that at the time of the judgment, the recorder could have been influenced by an unconscious or settled prejudice against the insurers of the party alleging bias as a result of this perspective. In support of this, a number of articles of the recorder were referred to. Furthermore, it was alleged that the findings of the recorder were favourable to the claimants and were evidence of the bias. The court held that taking a broad common sense approach, a person holding pronounced pro-claimant anti-insurer views expressed by the recorder in the articles, might unconsciously have weighed in favour of the claimant and against the defendant in resolving the factual issues before them and that there was a real danger of bias. The fact that the recorder had disclosed his affiliation to a pro claimant association did nothing to impress the court. The court acknowledged that there was a long established tradition that the writing of books or the editing of textbooks is not incompatible with holding judicial office. However, such judicial officer should: 
[...] exercise considerable care not to express himself in terms which indicate that he has preconceived views which are so firmly held that it may not be possible for him to try a case with an open mind. ${ }^{39}$

In this opinion the court was correct in its assessment that it was not the actual bias of the recorder that was important. Rather it was the fact that a reasonable person aware of the recorder's intellectual activity would conclude that there was a real likelihood that he will be biased.

The fourth case in Locabail is Williams $v$ Inspector of Taxes, ${ }^{40}$ where the court declined to find bias in the fact that the chairman of a tribunal who had sat over a complaint of sexual harassment and race discrimination levelled against the Internal Revenue, had been employed a long time before the hearing in a junior position in the internal revenue. In the last case, $R v$ Bristol Betting and Gaming Licensing Committee, ex parte O'Callaghan, ${ }^{41}$ the court declined to grant the permission to appeal on the grounds that the nonexecutive directorship of a judge in a company owning properties which were rented by a party in a case before him and of which he claimed he knew nothing, did not raise a real likelihood of bias. It is submitted that the court was right in its application of the test in Williams, while in Bristol Betting, it sought proof of actual bias and relied on the fact that the judge was a non-executive director and the truth of his assertion that he did not know that they were tenants of his company. Again it is likely that a fair-minded observer who knows that the party is a tenant of the judge's company will feel that there is a danger/likelihood of bias, even with the assertion of the judge that he did not know of the tenancy.

The change of the "reasonable suspicion" test was heralded in In re Medicaments and Related Classes of Goods (No. 2), ${ }^{42}$ where the Court of Appeal acknowledged that the test formulated in Gough had not commanded

39 Ibid at $\mathrm{p} 91$.

40 Hereafter Williams.

41 Hereafter Bristol Betting.

42 In re Medicaments and Related Classes of Goods (No. 2) [2001] 1 WLR 700. 
universal approval ${ }^{43}$ and did not seem in tune with the jurisprudence of the European Court of Human Rights in Strasbourg ${ }^{44}$ and that there was, therefore, a basis for review. Accordingly, the court conducted a review and stated that:

When the Strasbourg jurisprudence is taken into account, we believe that a modest adjustment of the test in $R v$ Gough is called for, which makes it plain that it is in effect, no different from the test applied in most of the Commonwealth and Scotland. The Court must first ascertain all the circumstances which have a bearing on the suggestion that the judge was biased. It must then ask whether those circumstances would lead a fair-minded and informed observer to conclude that there was a real possibility or a real danger, the two being the same, that the tribunal was biased. ${ }^{45}$

In Porter the House of Lords adopted this formulation of the test with the deletion of the phrase "real danger" and summarised the rule thus:

The question is whether the fair-minded and informed observer, having considered the facts, would conclude that there was a real possibility that the tribunal was biased. ${ }^{46}$

It is clear that the "modest change" effected by the court was, by the addition of the phrase "fair-minded and informed observer", to give the impression that it is the view of the observer and not the court, approved by Gough that is relevant. What is apparent from the consideration of the cases below is that the court undertakes the analysis of the "fair-minded and informed person".

The application of the real possibility test will now be considered. In Porter the allegation was that the auditor, who was involved in the assessment of whether political considerations had beclouded the implementation of a housing policy, gave a press conference where he made remarks on his

43 The decision was criticised or not followed in many commonwealth countries. In Australia, see Webb v R (1994) 181 CLR 41. In South Africa: $R$ v Roberts 1999 (4) SA 915 (SCA) (hereafter Roberts). In Scotland see Bradford v McLeod 1986 SLT 244; Millar $v$ Dickson 2001 SLT 988. Cf Lord Browne-Wilkinson in Pinochet 2 (n 6 above at p 598).

44 See Piersack v Belgium (1982) 5 EHRR 169; De Cubber v Belgium (1984) 7 EHRR 236; Pullar v UK (1996) 22 EHRR 391; and Hautschildt v Denmark (1989) 12 EHRR 266.

$45 \quad \mathrm{~N} 42$ at $\mathrm{p} 726-727$.

$46 \quad \mathrm{~N} 6$ at $\mathrm{p} 507$. 
provisional findings. The Court held that the main impression that would have been conveyed to a fair-minded observer was that the purpose of the press conference was to attract publicity to the auditor and that was an exercise in self-promotion that should not have been engaged in. The press conference was not indicative of bias, because in the context of the investigation he was carrying out and in his subsequent behaviour, there was no real possibility of bias. The court was quick to discountenance the personal assurances of the auditor that he was not biased and viewed the matter holistically.

In Taylor $v$ Lawrence, ${ }^{47}$ the judge presiding over a boundary dispute informed the parties that he had been a client of the claimant's solicitors but that it had been many years since he had instructed them. Nobody objected to his continuing to hear the trial. After judgment was given for the claimants, the defendants appealed on the grounds, inter alia, that there was an appearance of bias because of the judge's relationship with the claimant's solicitors. Before the hearing of the appeal, it was disclosed to the defendants that the judge and his wife had used the solicitor's services to change his will a night before the judgment was given. The appeal was dismissed and subsequently the defendants learned that the judge had not paid for the services. The defendants applied to reopen the appeal on the grounds that the judge had received financial benefit from the solicitors, which it had failed to disclose and that the earlier appeal had been dismissed in ignorance of that fact. The issue before the court was whether having also disclosed that the solicitors held the will, his failure to disclose also that the solicitors were currently instructed in relation to it gave rise to a fear in a fair-minded and informed observer of a real possibility that the judge's judgment would be influenced by that current relationship. The Court of Appeal held that for purposes of applying the test of apparent bias, the informed observer could be expected to be aware of the legal traditions and culture of the English jurisdiction and accordingly, he would be aware that contacts between the judiciary and the legal profession should not be regarded as giving rise to a possibility of bias. On the contrary, they promoted an atmosphere that was totally inimical of bias and what was 
true of social relationships was equally true of normal professional relationships between a judge and the lawyers he might instruct in a private capacity. It is argued that the facts of this case and its application by the court also illustrate the fact the real possibility test is all about a court personifying the reasonable man and assessing the evidence. The court clearly raised a presumption that was attributable to a reasonable man as a basic foundation of his perception. In any case, it seems a little difficult to believe that there is no real possibility of bias when a judge in a matter makes a partial disclosure and proceeds to meet the solicitors of a party before him, without the presence of the other party or his solicitor. It is submitted that this is one case where a real possibility of bias existed.

After Taylor, the case of Lawal v Northern Spirit, ${ }^{48}$ demonstrates the return of English Courts in the application of the Porter test to the manifest justice principle as it dealt with the issue of subconscious bias ${ }^{49}$ arising from a relationship of trust and confidence. The standard after Lawal is a lower threshold that judicial officers and administrators must pass to be regarded as impartial and is justified by the court on the modest shift by the House of Lords in Porter, based on the need to maintain public confidence in the judiciary. The facts of Lawal are that in the course of an appeal to the Employment Appeal Tribunal, the senior counsel instructed by the employer had previously sat as a part-time judge (a recorder) ${ }^{50}$ with one of the lay members of the Appeal Tribunal. The claimant raised an objection that there was a real possibility of subconscious bias on the part of the lay member. Without ruling on that objection, the tribunal ordered that the appeal should be heard by a differently constituted tribunal, but considered the point on principle and held that there was no real possibility of bias when the only objection

47 Taylor v Lawrence [2002] 2 ALL ER 353 (hereafter Taylor).

48 Lawal v Northern Spirit Ltd [2004] 1 ALL ER 187 (hereafter Lawal).

49 In Gough (n 6 above at p 728) Lord Goff said: "... bias is such an insidious thing that even though a person may in good faith believe that he was acting impartially, his mind may unconsciously be affected by bias".

50 The practice before this case was that the Lord Chancellor would appoint leading counsel who are recorders and experienced in employment law to sit as part time judges in the Employment Appeal Tribunal and they undertake to sit for at least 20 days a year. 
against the Employment Appeal Tribunal was that either one or both of the lay members had previously sat with a recorder who, as counsel, was appearing for a party at the appeal. The majority of the Court of Appeal affirmed the decision of the Appeal Tribunal hence the appeal to the House of Lords. However, the court was not unanimous. Mummery LJ who was with the majority said:

The Recorder objection amounts to no more than an assertion that a lay member might possibly be more disposed to accept the submissions of one party's legal representative than those of other side, as a result of the professional experience of having sat on the tribunal with him in his capacity as a part time judge. That is merely a speculative and remote possibility based on an unfounded and, some might think, condescending assumption that a lay member sitting with another judge on the hearing of an appeal cannot tell the difference between the impartial decision-making role played by a tribunal panel of a judge and two lay members and the adversarial role of the partisan advocates appearing for the parties. ${ }^{51}$

Lord Phillips $\mathrm{mr}$, who was also with the majority, stressed the fact that the frequency of the recorder's sitting would determine the issue of the appearance of bias such that the more the recorder sat, the greater the likelihood that he would appear to the litigant as a judge of the tribunal rather than an advocate that sometimes sits as a judge. In his dissenting opinion Pill LJ stated that:

The fair minded and informed lay observer will readily perceive, I have no doubt, the collegial spirit in which the Appeal Tribunal operates and the degree of trust which lay members repose on the presiding judge. It is my judgment likely to diminish public confidence in the administration of justice if a judge who enjoys that relationship with lay members, with the degree of reliance placed on his view of the law, subsequently appears before them as an advocate. The fair minded observer might well reasonably perceive that the litigant opposed by an advocate who is a member of the tribunal and has sat with the lay members is at a disadvantage as a result of that association. A litigant's doubt about that impartiality ... would, for the reasons given,

They were also allowed to appear before the tribunals of which they were part time members.

51 See n 48 above loc cit par 8 . 
be a legitimate doubt. In my view, the procedure does not inspire public confidence. ${ }^{52}$

The House of Lords agreed with the minority opinion. The court, in accordance with the test in Porter, held that the practice whereby part time judges in the Employment Appeal Tribunal might appear as counsel before a tribunal, having previously sat with one or more lay members of the bench hearing the appeal should be discontinued, as a fair-minded and informed observer, having considered the given facts, would conclude that there was a real possibility that the lay member might be subconsciously biased. The court believed that the observer was likely to approach the matter on the basis that the lay member looked to the judge for guidance on the law and could be expected to develop a fairly close relationship of trust and confidence with the judge. The Lords in a manner attributed constructive notice of two facts to the "fair-minded and informed lay observer". The first fact was that a recorder in a criminal case who had sat with jurors might not subsequently appear in a case in which one or more of the jurors served, ${ }^{53}$ while the second fact is that parttime chairmen of employment tribunals are prohibited from appearing as counsel before the tribunals of which they have acted as chairman. ${ }^{54}$ The Lords seemed ready to move beyond convention and practice since they rejected the argument that the practice of part time judges appearing before the tribunal had been going on for some time, an argument that would have been consistent with the attitude of the Court of Appeal in Taylor. Thus Lord Steyn stated that:

The indispensable requirement of public confidence in the administration of justice requires higher standards today than was the case even a decade or two ago. The informed observer of today can perhaps 'be expected to be aware of the legal traditions and culture of this jurisdiction' as was said in Taylor $v$ Lawrence ... But he may not be wholly uncritical of this culture. ${ }^{55}$

52 Ibid par 9.

53 See par 30 of the Policy Procedure and Terms and Conditions of Service of Recorders.

54 See par 16 of the Terms and Conditions of Service and Terms of Appointment of PartTime Chairmen of Employment Tribunals.

55 See n 47 above at par 22. 
Lawal is certainly a shift noticeable from Pinochet 2 of the readiness of the English judiciary to more readily find bias, a position which is entirely consistent with the manifest justice principle. There is no doubt that the effect of a lower threshold on later cases will be pervasive and that will be welcome. A discussion of the two tests, which have been used in South Africa, follows.

\subsection{The reasonable suspicion test in South Africa}

The "reasonable suspicion" test for apparent bias was laid down in the case of BTR Industries South Africa (Pty) Ltd v Metal and Allied Workers Union. ${ }^{56}$ In this case, the Appellate Division stated that:

... in our law the existence of a reasonable suspicion of bias satisfies the test; and that an apprehension of a real likelihood that the decision maker will be biased is not a prerequisite for disqualifying bias. The test is that of a 'reasonable suspicion'. ${ }^{57}$

This case is a clear case of a reasonable suspicion of bias because in the course of a long-drawn case between labour and management, the President of the Industrial Court participated in a seminar arranged by management's industrial relations consultants in which management's lawyers all presented papers. In Roberts, ${ }^{58}$ the Supreme Court of Appeal clarified this test. Howie JA said:

The requirements of the test for the appearance of judicial bias are as follows as applied to judicial proceedings: (1) There must be a suspicion that the judicial officer might, not would, be biased. (2) The suspicion must be that of a reasonable person in the position of the accused or the litigant. (3) The suspicion must be based on reasonable grounds. (4) The suspicion is one which the reasonable person referred to would, not might, have. ${ }^{59}$

The court was quick to emphasise that:

56 See $\mathrm{n} 15$ above.

57 At p 693. Cf Council of Review, SADF v Monning 1992 (3) SA 482 (A) (hereafter Monning); Moch v Nedtravel 1996 (3) SA 1 (A) (hereafter Moch); De Lille v Speaker of the National Assembly 1998 (3) SA 340(C); Ighayiya Technical College $v$ Member of the Executive Council for Education, Eastern Cape 1998 (4) SA 502 (Ck). 
... if the suspicion of bias is one based on reasonable grounds the reasonable person would have it. If it were not so founded the reasonable person would not have it. ${ }^{60}$

The reasonable suspicion test became entrenched in the decision of the English Court of Appeal in Metropolitan Properties which was given nine years after Barnsley Justices elaborated the real likelihood of bias test. It is the opinion that this test too sought to move away from the "mere suspicion" test, even though there are dicta in the judgment that the court in Metropolitan Properties was following the Sussex Justices formulation of Lord Hewart CJ. ${ }^{61}$

The use of the word "reasonable" imports some subjectivity, which, in turn, contemplates a discretion and relies on the views of the proverbial reasonable man which is quite often nothing more than the views of the court. Lord Goff recognised this point in Gough when he argued that a comparison of the opinion of Denning mr in Metropolitan Properties and that of Devlin LJ in Barnsley Justices shows that there was no significant difference between the real likelihood of bias test and the real danger test except that:

Whereas Devlin LJ spoke of the impression which the court gets from the circumstances, Lord Denning $\mathrm{mr}$ looked at the circumstances from the point of view of a reasonable man ... Since however the court investigates the actual circumstances, knowledge of such circumstances as are found by the court must be imputed to the reasonable man; and in the result it is difficult to see what difference there is between the impression derived by a reasonable man to whom such knowledge has been imputed and the impression derived by the court, here personifying the reasonable man. ${ }^{62}$

The element that Howie JA added in Roberts - that the suspicion is one which a reasonable person would, not might, have - further confirms the shift away from the "mere suspicion" test and demonstrates the discretion given to the court to determine what suspicion a reasonable person would have. In a

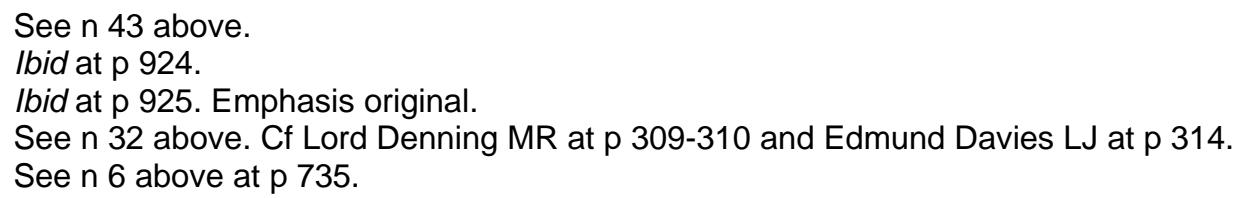


penetrating analysis of the difference between the "real likelihood/danger test" and "reasonable suspicion" test, Howie JA stated that:

With the greatest respect I venture to say that there is an important distinction between assessing the appearance of bias through the eyes of a trained and experienced judicial officer and assessing it through the eyes of a reasonable person even with the latter possessing all the relevant knowledge ... Certainly, in eliminating the reasonable observer the real danger test is more direct and no doubt the reasonable man although required to have reasonable grounds, would necessarily be judged as viewing the events and circumstances from the subjectivity of being, notionally, litigant or accused. However the real danger test may well do no more than switch one element of subjectivity for another. The members of the court applying that test are by training and experience as judicial officers themselves, better equipped, it is true, to exercise objective judgment than a lay litigant but it is that very training and experience which gives them a subjective position and knowledge not possessed by the notional reasonable person. They might know that a judicial officer's behaviour and comment unfortunately can, on infrequent occasions, be in appropriate but without any real danger of bias as not real where the reasonable impression of bias would nonetheless reasonably lodge in the mind of a reasonable person suitably informed ... ${ }^{63}$

It is our submission that the same argument can be made as to the reasonable man who, based on certain assumptions, would hold that no bias appears while members of the public who depend on "mere suspicion" would feel that there is an appearance of bias. Be that as it may, it seems unlikely for a court to assess bias from a reasonable man's point of view without interposing its judicial training. This point will be returned to later.

\subsection{The reasonable apprehension test in South Africa}

In SARFU 2 the Constitutional Court of South Africa adopted the reasonable apprehension test ${ }^{64}$ and laid down the proper approach to the application of recusal of members of a court. The court stated that:

63 Par 36.

64 This test has been adopted in Lesotho: Sole v Cullinan [2003] 3 All SA 466 (Les CA). For an analysis of this case see Okpaluba 2004 TLR 1. It has also been followed in Swaziland. See Minister of Justice v Sapire (civ App 49/2001, 10.6.02 unrep). 
It follows from the foregoing that the correct approach to this application for the recusal of members of this court is objective and the onus of establishing it rests upon the applicant. The question is whether a reasonable, objective and informed person would on the correct facts reasonably apprehend that the judge has not or will not bring an impartial mind to bear on the adjudication of the case that is a mind open to persuasion by evidence and the submissions of counsel. The reasonableness of the apprehension must be assessed in the light of the oath of office taken by the Judges to administer justice without fear or favour; and their ability to carry out that oath by reason of their training and experience. It must be assumed that they can disabuse their minds of any irrelevant personal beliefs or predispositions. They must take into account the fact they have a duty to sit in any case which they are not obliged to recuse themselves. At the same time it must never be forgotten that an impartial Judge is a fundamental prerequisite for a fair trial and a judicial officer should not hesitate to recuse herself or himself if there are reasonable grounds on the part of litigant for apprehending that the judicial officer, for whatever reasons, was not or will not be impartial. ${ }^{65}$

The distinguishing feature of the reasonable apprehension test in SARFU 2 is the presumption of judicial impartiality. ${ }^{66}$ An examination of the cases of $S V$ Malindi, ${ }^{67}$ Monning, ${ }^{68}$ BTR industries and Roberts will show that in none of the cases the presumption of judicial impartiality was used. SARFU 2 introduced it and it radically altered the reasonable suspicion test that it may be safe to regard the correct test in South Africa now to be the "reasonable apprehension" test. Mithiyane AJA in Sager $v$ Smith $^{69}$ argued that the use of "apprehension" instead of "suspicion" is a difference in terminology, which has

65 Ibid at par 48. The court relied on the decision of the Canadian Supreme Court in $R \vee S$ (RD (1997) 118 CCC (3d) 353.

66 On the presumption of judicial impartiality the Constitutional Court cited with approval, the dictum of Cory $\mathrm{j}$ in $R \vee S(R D)$ ibid at par 117: "Courts have rightly recognized that there is a presumption that judges will carry out their oath of office ... This is one of the reasons why the threshold for a successful allegation of perceived judicial bias is high. However, despite this high threshold, the presumption can be displaced with 'cogent evidence' that demonstrates that something the judge has done gives rise to a reasonable apprehension of bias".

67 S v Malindi 1990 (1) SA 962 (A): The matter must be regarded from the point of view of the reasonable litigant and the test is an objective one. The fact that in reality the judicial officer was impartial or likely to be impartial is not the test. It is the reasonable perception of the parties as to his impartiality that is important" at $\mathrm{p} 969(\mathrm{H})$.

68 See n 57 above at p 880(E-F): "the appearance of impartiality has to do with the public perception of the administration of justice."

69 Sager $v$ Smith 2001 (3) SA 1004 (SCA) par 15: "The difference would appear to be one of semantics rather than substance." 
no significance. ${ }^{70}$ With due respect it does seem that it has significance. Apart from the fact that apprehension is a more appropriate term for the objective test laid down in SARFU 2, suspicion connotes a subjective state of mind. As stated above, the presumption of judicial impartiality represents the change to the test as laid down in BTR Industries and amplified in Roberts. That a new test $^{71}$ is introduced by SARFU 2 is evident in SACCAWU 1, where the Constitutional Court in a majority judgment further explained the test. In the opinion of the court:

In formulating the test the Court observed that two considerations are built into the test itself. The first is that in considering the application for recusal, the court as a starting point presumes that judicial officers are impartial in adjudicating disputes. As later emerges from the SARFU judgment, this in-built aspect entails two further consequences. On one hand, it is the applicant for recusal who bears the onus of rebutting the presumption of judicial impartiality. On the other hand, the presumption is not easily dislodged. It requires 'cogent' or 'convincing' evidence to be rebutted. The second in-built aspect of the test is that 'absolute neutrality' is something of a chimera in the judicial context. This is because judges are human. They are unavoidably the product of their own life experiences, and the perspective thus derived inevitably and distinctively informs each judge's performance of his or her judicial duties. But colourless neutrality stands in contrast to judicial impartiality - a distinction the SARFU decision vividly illustrates. Impartiality is that quality of openminded readiness to persuasion-without unfitting adherence to either party, or to the judge's own predilections, preconceptions and personal views - that of a civilized system of adjudication. Impartiality requires in short a mind open to persuasion by the evidence and the submissions of counsel; and in contrast to neutrality, this is an absolute requirement in every judicial proceeding ... The court in SARFU further alluded to the apparently double requirement of reasonableness that the application of the test imports. Not only must the person apprehending bias must be a reasonable person, but the apprehension must in the circumstances be reasonable ... The 'double' unreasonableness requirement also highlights the fact that mere apprehensiveness on the part of the litigant that a judge will be biased - even a strongly and honestly felt anxiety - is not enough. The court must carefully scrutinize the apprehension to determine whether it is to be regarded as reasonable. In adjudging this, the court superimposes a normative assessment on the litigant's anxieties. It

70 Cf Hoexter, Lyster and Currie Constitutional and Administrative Law 192 and Devenish 2000 TSAR 397.

71 See Okpaluba 2003 JJS 109. 
attributes to the litigant's apprehension a legal value, and thereby decides whether it is such that should be countenanced by law. ${ }^{72}$

The court went further to state that determining the objective legal value in South Africa involves "fraught considerations ... because the administration of justice", emerging as it has from "the evils and immorality of the old order", remains vulnerable to attacks on its legitimacy and integrity. ${ }^{73}$ In the court's opinion, two factors must be borne in mind in determining this legal value:

On one hand, it is vital to the integrity of our courts and the independence of judges and magistrates that ill-founded and misdirected challenges to the composition of a bench be discouraged. On the other, the courts' very vulnerability serves to underscore the pre-eminent value to be placed on public confidence in impartial adjudication. In striking the correct balance, it is 'as wrong to yield to a tenuous or frivolous objection' as it is 'to ignore an objection of substance'. ${ }^{74}$

It is the determination of this objective legal value that is fraught with grave danger. Again, as stated above, the court personifies the reasonable man in doing so and often requires proof of the bias as establishing the legal value. As Smith-Brown LJ stated in Dallaglio (in a dictum approved by Howie JA in Roberts):

It will be seen therefore that by the time the legal challenge comes to be resolved, the court is no longer concerned strictly with the appearance of bias but rather with establishing the possibility that there was actual although unconscious bias. ${ }^{75}$

It is, therefore, apparent that where there is no proof, the legal value will not be met. This manner of proceeding is far from assessing an apprehension of bias, even if it is consistent with the introduction of a reasonable apprehension test. 
The dissenting opinion of Mokgoro and Sachs jj in SACCAWU 1 put the author's argument in proper perspective:

The test for recusal places a heavy burden of persuasion on the person alleging judicial bias or its appearance. But despite the presumption in favour of judges' impartiality, the test requires an assessment of the litigant's perception of impartiality .... A judge called upon to decide whether or not a disqualifying apprehension of bias exists, however should consider the apprehension of the lay litigant alleging bias and the reasonableness of that apprehension based on the actual circumstances of the case. As Cameron AJ points out, the lay litigant is assumed to be well-informed and equipped with the correct facts. But the lay litigant should not be expected to have the understanding of a trained lawyer and to appreciate the implications of the different nature of the appeal process. In both cases it will be the judges who decide and who must have an open mind. In all circumstances, the test emphasizes reasonableness in the light of the true facts, not the technical nuances of the particular case. It is our contention that the reasonableness of the apprehension also requires that the judge assess the lay litigant in her or his context. ${ }^{76}$

It is submitted that the minority opinion accords with the reasonable suspicion test laid down in BTR Industries and Roberts.

The contending views in SACCAWU 1 led to different assessments of the allegation of bias. When the applicant's appeal against the industrial court's refusal to grant them unfair labour practice relief was called in the Labour Appeal Court, they moved for the recusal of two of the three judges on the grounds that they reasonably apprehended bias against their appeal. The application was refused hence the appeal. Thirty-five applicants were dismissed on 2 August 1995 for participation in a demonstration in the respondent's factory on 21 June $1995 .^{77}$ Consequent to the dismissal the union representing the applicants organised a demonstration protesting the dismissal between 25 and 31 August 1995. Another thirty-five employees were consequently dismissed of which seventeen were under final written 
warning for participating in the 21 June march. ${ }^{78}$ The two groups of employees brought separate proceedings for unfair labour practice relief in the industrial court. The first to reach trial were the Nomoyi employees. The industrial court confirmed the dismissal of the seventeen under final written warning but reinstated the remaining eighteen. Both parties appealed to the Labour Appeal Court and this court confirmed all thirty-five dismissals. Subsequently the Nkatu workers came to the labour court, five weeks after the Nomoyi workers and when that court dismissed their applications they proceeded to the Labour Appeal Court. The application for the recusal of the two Judges of the Labour Appeal Court was based on the judgment given by the court in the Nomoyi matter. The applicants argued that the facts of the cases were the same and that the Labour Appeal Court's "findings" in the Nomoyi matter, specifically the findings of what happened on 21 June, had led to a mental picture which the judges would find difficult to abandon. These findings were a condemnation of the conduct of the union, which the applicants considered critical, as it was important in determining whether the protesters had a common purpose. Furthermore, the applicants alleged that the credibility of three witnesses had already been pronounced upon in Nomoyi. Their reliance on these issues was not to assess whether the judges were justified in their conclusions but the apprehension it would cause in the minds of reasonable persons in the position of applicants. The majority of the Constitutional Court held that there was no basis for the allegation because there was no live and significant issue in the Nkatu appeal on which (or about the credibility of a witness significant to which) the judges expressed "clear views" in Nomoyi. ${ }^{79}$ The court held that the events of the June 21 march were

78 Referred to by the Court as Nomoyi who was the first applicant.

79 The court adopted the test in Livesey $v$ New South Wales Bar Association (1983) 151 CLR 288 where the court held that a fair-minded observer might entertain a reasonable apprehension of bias if a judge sits to hear a case at first instance after he has, in a previous case, expressed clear views either about a question of fact which constitutes a live and significant issue in the subsequent case or about the credit of a witness whose evidence is of significance on such question of fact. The court doubted whether the case of $R v T 1953$ (2) SA 479 (A) was good law. Counsel for the employer relied on this case as authority that "there was no rule in South Africa which lays down that a judge in cases other than appeals from his judgments is disqualified from sitting in a case merely because in the course of his judicial duties he has previously expressed an opinion in that case". In that case the Appellate Division dismissed the contention that a magistrate 
not an issue in the Nomoyi trial as the court was not asked to pronounce on the merits and demerits of that march, but on the justification of the dismissals. Consequently a reasonable litigant would attribute appreciably less significance to the courts' recounting of the background evidence. Moreover the court held that:

... the presumption of judicial impartiality will apply with added force in an appellate court, where the law rightly supposes that the reasonable litigant will have knowledge of the institutional aspects that operate to guarantee a fair appreciation of his or her appeal. ${ }^{80}$

In addition, there were obstacles in the way of applicants in furnishing "cogent" and "convincing" evidence of reasonably apprehended bias. The court further noted that the evidence of certain observations made by one of the judges ${ }^{81}$ was not canvassed before the Labour Appeal Court, thus depriving the judges of an opportunity of hearing the arguments and their

ought to have recused himself because on uncontested evidence, he had found one party to a sexual act guilty, and thereafter on contested evidence in a second trial where the previous accused was called to testify for the prosecution, he convicted the other party. They also contended that $R \vee T$ had been approved in $R v$ Somciza 1990 (1) SA 361 (A) and had been cited in SARFU 2. In $R v$ Somciza the Appellate Division held that a magistrate whose decision convicting an accused had been set aside on appeal should not preside at a resumed hearing. The magistrate had made "strong credibility findings" in respect of all State witnesses in which he accepted their evidence. The court in $R v$ Somciza had distinguished $R v T$ on the grounds that he was trying a different accused person. The Constitutional Court held that the SARFU 2 Court cited $R v T$ as "authority for the proposition that Canadian case dealing with the presumption that a judicial officer will act impartially in any matter that he or she is called upon to decided were consistent with our law". It was not necessary in SARFU 2 to consider the application of that principle to the facts in $R \vee T$, and SARFU 2 is not authority for the proposition that the failure of the magistrate to recuse himself in such circumstances would be consistent with the substantive elements of the constitutional right to a fair trial. In any event, for $R v$ $T$ to constitute good law today, it would have to survive the test set out above, namely whether the magistrate had already in the earlier trial decided an issue that was "live and significant" in the second trial (par 38).

80 Par 43.

81 The observations include a comment in allowing the employer's cross appeal in Nomoyi that those employees who were under final warning for the June 21 episode in the Nkatu episode and dismissed in Nomoyi "doubly deserved to be dismissed". Secondly, the judge referred to the confrontational attitude displayed by the workers leaders and by SACCAWU. Thirdly, in determining the character of the August demonstration, the judge referred to the determination of the union to build on the defiant image it had begun to establish in June 1995. 
comments thereon. ${ }^{82}$ The minority stressed that it was not the influence of the knowledge of the first trial on the second trial that was in issue by stating that:

... we are fully confident that, given their training and experience, the judges concerned would be able to set aside any knowledge gained in the course of their hearing of the first matter and disabuse themselves of any opinion they may have formed. ${ }^{83}$

In their opinion the critical issue was the apprehension of the lay litigant. The minority contended that:

Indeed the events and findings appear to overlap so closely that the applicants fear that they will not get the 'fair hearing before a court or, where appropriate, another independent and impartial tribunal or forum' guaranteed by section 34 of the Constitution. We believe that any lay litigant in the position of the applicants would entertain such apprehension, and that in the very special circumstances of the case where forceful pronouncements by the judges' concerned have already been made on crucial matters in issue, they would not do so unreasonably. ${ }^{84}$

It is important to note that the court was unanimous that an "actual, live concrete and highly relevant issue" is a critical factor in the apprehension of bias. $^{85}$ While the majority sought to show that this was not present in this case, the minority sought to prove that it was present and sufficient to substantiate a reasonable apprehension from a lay litigant's perception. While it is agreed that that the minority were correct as to the interpretation of the cognizable apprehension, it may have been wiser to have insisted only on the apprehension of the lay litigant. An attempt to prove the live and actual issue again - entirely consistent with the reasonable person test - is the path to the replacement of the opinion of the reasonable and fair-minded observer with that of the court.

Given the position of the minority, in SACCAWU 1, it is arguable that the decision in SARFU 2 would have been different. Be that as it may, it is

82 The minority was quick to point out the need to put substance over form.

83 Par 57.

84 Par 60. 
possible to explain the decision in SARFU 2 on its unique facts. Accordingly, it is probable that the prospect that the whole court or a majority of the court would have recused themselves creating a constitutional vacuum because it would have been unconstitutional for any other court to hear the case, is the underlying rationale for the decision in that case. This fact, evident in the consideration of the court, ${ }^{86}$ may in some sense have driven the court to import the presumption of judicial impartiality as a reaction to judge-shopping. It would have been appropriate for the majority in SACCAWU 1 to have realised this point and departed from it, even if indirectly. This is the path that the minority took. Unpleasant as it appears, it is submitted that an application of the minority judgment would find an apprehension of bias from a reasonable lay litigant's view in SARFU 2. If nothing else, the correspondence between Chaskalson $P$ and the applicants ${ }^{87}$ for recusal sustains this bias along with the specific allegations made against the whole court and specific judges. ${ }^{88}$ This is more so as the court agreed to a "basket approach" which was to take into account the cumulative effect of the facts and complaints made against the judges concerned. ${ }^{89}$ The presumption of judicial impartiality and its component parts enabled the court to seek "cogent" and "convincing"

85 Par 63.

86 Note par 9: "This Court sits en banc and all of its available members are expected to sit in every case. Its quorum is eight of its members. If the five judges were to have recused themselves the quorum would have been broken and the appeal would not have been able to proceed."

87 In a reply seeking clarification on the relationship between members of the Constitutional Court and Mr Nelson Mandela, the then President of the Republic of South Africa, Chaskalson $P$ replied and stated thus: "If the case has political overtones that is of no concern to the Court. Its duty is to decide the case in accordance with the law and the evidence and that is what it will do. The suggestion that your client has reason to believe that because he and Mr Mandela are leaders of a political parties, and because the judges of this court have been appointed by Mr Mandela, he might not get a fair hearing, and that under those circumstances members of this [C]ourt might not be objectively and impartially able to adjudicate on the credibility of the President, is improper and without substance ... There is no basis for the slander of the Court contained in your letter". Ibid par 12.

88 The allegations were that every member of the Constitutional Court would be biased against him and that as a result he would not get fair hearing. In addition to the general averments, the applicant went ahead to make specific averments pertaining to the President and Deputy President of the Court and three of its members, Kriegler, Sachs and Yacoob jj. The allegations concerned political social family and personal relationships with Mr Nelson Mandela, the then President of the Republic of South Africa.

89 Ibid at par 49. 
reason to rebut the presumption. In doing this, the court may have been looking for proof of actual bias. This is evident in the opinion of the court that:

An unfounded or unreasonable apprehension concerning a judicial officer is not a justifiable basis for such application. The apprehension of a reasonable person must be assessed in the light of true facts as they emerge at the hearing of the application. It follows that incorrect facts which were taken into account by an applicant must be ignored in applying the test. ${ }^{90}$

As stated earlier, the practical effect of the reasonable apprehension test is to raise the threshold for the finding of apparent bias. In this sense it resembles the "real danger/likelihood" test formulated in Gough. If a litigant has to discharge the onus of rebutting the presumption of judicial impartiality with "cogent" evidence that is akin to a proof of the bias, it is without doubt similar to the "real danger/likelihood of bias" test

It is the opinion that the interpretation of the reasonable apprehension test laid down by the minority in SACCAWU 1 is far more acceptable. Even at that, there are still some misgivings with their approach. However as argued above, the use of the word "reasonable" really turns the test into what the court regards as "reasonable" and not what the lay litigant apprehends. It is for this reason that the manifest justice principle is advocated to guide the courts in their assessment of the facts alleged to sustain that apparent bias. Using the principle will continually remind the courts of the need to maintain public confidence in administration of justice.

A review of the cases of applications for recusal based on the SARFU 2 test follows. What these cases indicate is that while they acknowledge that the test is that of reasonable apprehension, in line with SARFU and SACCAWU 1, their interpretation of the test differs. While some of the courts apply the test as interpreted by the majority, some others adopt the minority interpretation in SACCAWU 1.

90 Par 45 (emphasis supplied). 
Some of the cases relate to the conduct of judicial officers a quo. The applications for recusal in these cases bring to the fore policy tensions between the need to prevent judge-shopping and the maintenance of public confidence in the administration of justice. While it may seem that the SARFU 2 test may be an excellent means of resolving this tension, it is also possible that the reasonable suspicion test applied from the perspective of the "reasonable, objective and informed litigant in possession of the correct facts" may also be worthy, as demonstrated by the Supreme Court of Appeal who used the test without recourse to the presumption of judicial impartiality in the case of Take \& Save Trading $v$ Standard Bank. ${ }^{91}$ In the course of the plaintiff's case and at a crucial stage when the last of the plaintiff's witnesses were to be cross-examined, the defendants' legal team withdrew without proffering any reason. The defendants represented by one of them applied for a postponement of the trial. The learned trial judge debated the merits of the postponement with him. During the course of the debate, the judge expressed in no uncertain terms that he thought that there was little merit in two aspects of the defendant's case, that the postponement would have amounted to an exercise in futility and that since the other defenses depended on the defendant's evidence, that he could proceed to give his evidence without the benefit of counsel. Eventually the judge granted a postponement. When the matter came up again, the defendants now represented by another counsel applied by way of notice of motion for the judge to recuse himself. He refused the application and the subsequent one for leave to appeal, hence the appeal. Harms j reviewed the evidence painstakingly and concluded that:

... a deadly legal point forcefully made by the court during argument cannot give rise to an impression of bias in the eye of the 'reasonable, objective and informed' litigant in possession of the 'correct facts'. ${ }^{92}$

The court quoted approvingly the dictum of Schreiner JA in $R v$ Silber: ${ }^{93}$

$91 \mathrm{~N} 4$.

92 Ibid par 17.

$93 \quad R$ v Silber 1952 (2) SA 475. 
The grounds relied upon for suggesting bias were not facts outside the course of proceedings such as are ordinarily put forward as reasons why the judicial officer in question should not try the case. The grounds related to purely to what had happened in the course of the trial. Neither counsel has been able to find any reported case in which an application for recusal has been made in the course of a trial on the ground that the judicial officer has shown bias by his conduct of the proceedings. And this is not surprising, since the ordinary way of meeting any apparent bias shown by the court in its conduct of the proceedings would be by challenging his eventual decision in an appeal or review. Bias as it is used in this connection, is something quite different from a state of inclination towards one side in the litigation caused by evidence and argument and it is difficult to suppose that any lawyer could believe that a recusal might be based on a mere indication, before the pronouncement of the judgment, that the court thinks that at that stage one or the other party has the better prospects of success ... Indeed a court may in proper case call upon a party to argue out of the usual order, thus clearly indicating that its provisional view favours the other party, but no reasonable person, least of all a person trained in the law, would think of ascribing this provisional attitude to, or identifying it with, bias. ${ }^{94}$

This decision demonstrates that it is not every allegation or "mere suspicion" that can sustain an allegation of bias.

In Sager $v$ Smith, ${ }^{95}$ the Supreme Court of Appeal applied the SARFU 2 test to find that the magistrate whose recusal was sought neither said nor did anything to give rise to a reasonable apprehension that he was biased against the defendant and that no reasonable person would entertain such belief on a proper appreciation of the facts. The complaints which formed the basis of the defendant's application for recusal related to rulings made by the magistrate in the course of the trial; the admission of photographs; the refusal to attend an inspection in loco and finally, comments that defendant's attorney was splitting hairs and wasting time on frivolous matters. The court examined each of the four grounds of complaint to find if there was any truth in them and in respect of the issue of comments conducted an interpretational exercise. Even though the decision of the court may be correct, it may have been better to weigh the complaints from the perspective of the reasonable litigant. The appropriate 
question would have been whether the four complaints do not raise a reasonable apprehension of bias.

In SACCAWU v President, Industrial Tribunal, ${ }^{96}$ the Supreme Court of Appeal did not use the presumption of impartiality, but rather sought to evaluate the conduct alleged to be biased. In this case, the applicants were dismissed from their employment for a number of reasons. The dismissed workers and their union brought an application before a tribunal that included an attorney for relief due to an unfair labour practice. In reaction to the verdict of the tribunal dismissing their claim, the applicants alleged bias on the part of two of the members of the tribunal. The applicants alleged that the tribunal treated their attorney discourteously, trying to show his ignorance. Another allegation, which for procedural reasons became the only issue for assessment of bias, is that an attorney, who is a member of the court told, them that they would have won the case had they hired him instead of their attorney. The court held that the comments did not constitute a reasonable apprehension of bias. The court deplored the conduct of the attorney, but explained away his conduct without even asking whether the applicants apprehended bias from the conduct of the member of the tribunal. It is the opinion that the court was wrong in evaluating the evidence rather than assessing the evidence from the viewpoint of the reasonable lay litigant. It is difficult to imagine the litigant that would not be alarmed when a member of the court rebukes him for hiring somebody else instead of himself. The litigant would walk away with the impression that the verdict of the court went the way it did because this point was being made. It cannot be imagined that any better example of self-interest should merit automatic disqualification.

Another case is Silwana $v$ Magistrate for the District of Piketberg ${ }^{97}$ where the court adopted the SARFU 2 test, but used the reasonable impression of the litigants as a basis for assessment of the allegation that a reasonable apprehension of bias arises due to the fact that the magistrate who signed a

96 SACCAWU v President, Industrial Tribunal 2001(2) SA 277 (SCA) (hereafter SACCAWU 2). 
search warrant was the person who presided over the trial and that certain portions of the affidavits had been deleted. The court, in holding that the two facts raised an apprehension of bias, stated that "[t]he reasonable apprehension by the person facing the judge is all important." 98 If the presumption of judicial impartiality had been used as the threshold it may have been possible to argue, as the magistrate did in refusing the application for the recusal, that his training was such that any evidence obtained in the course of the issuance of the search warrant will not affect him during the trial. The court was right to depend on the apprehension of the litigants as to the contents of the missing part of the affidavit. Not even the assurance by the prosecutor that the missing part of the affidavit was the identity of the informants could sway the court.

The utility of the use of a reasonable apprehension test as opposed to mere suspicion is found in the cases of allegations of bias arising from the personal characteristics of the judicial officer rather than some personal conduct. Thus in $S v$ Collier, ${ }^{99}$ the court made it clear that bias cannot exist simply because of the race of the judge. ${ }^{100}$ In Shackell $v S,{ }^{101}$ the Supreme Court of Appeal reaffirmed this principle. Using the SARFU 2 test, it assessed an application for recusal of a black judge on the grounds that the judge's son had been killed by white policemen and as such, the applicant, a white policeman would not get a fair trial because the black judge would be biased on account of the similarity of the death for which the policeman is charged and the brutal death of the judge's son. The appellant conceded that the two incidents were too far apart to be of any consequence, but alleged that the decision of the Truth and Reconciliation Commission on an amnesty application by the white policeman who killed the judge's son was imminent and thus the facts of the previous case would be fresh in the judge's mind. The court held that:

97 Silwana v Magistrate for the District of Piketberg [2003] 3 All SA 350 (C).

98 Ibid at $\mathrm{p} 355$.

99 S v Collier 1995 (8) BCLR 975 (C).

100 Cf Wildlife Society of Southern Africa v Minister of Environmental Affairs and Tourism of the Republic of South Africa [1996] 3 All SA 462 (Tk). In this case an application of 
... the norm of the reasonable man is, of course, a legal standard. In bringing that legal standard to bear on the present facts the appellant in my view has failed by a substantial margin to rebut the weighty onus which rested on him. ${ }^{102}$

These are welcome judgments, lest every personal characteristic such as religious, gender and sexual inclination will become without more a reason for objection. It is also important to note that there may be circumstances where, by the conduct of the judicial officer, some personal characteristic becomes in issue, just as seen in Timmins v Gormley - one of the Locabail cases.

It is evident from the consideration of the cases that the minority opinion in SACCAWU 1 remains very attractive and should be cause for reflection by the Constitutional Court so that it may reconsider the test as laid down in SARFU 1 at the earliest opportunity.

\section{The reasonable apprehension test in Canada and Australia}

In this section the test for judicial bias in Canada and Australia, which is the reasonable apprehension test, will be considered. As stated above, the reasonable apprehension test in South Africa was based on the decision of the Canadian Supreme Court in $R v S(R D) .{ }^{103}$ It is instructive that the test in Australia is also the same and some of the leading cases in that country were relied upon in the decision of the majority in SACCAWU 1.

recusal on the fact that the judge lived in an area that was subject matter of litigation was rejected.

101 Shackell v S [2001] 4 All SA 279 (A).

$102 \mathrm{Ibid}$ at $\mathrm{p} 286$.

103 N 65. 
In Canada, the test for reasonable apprehension of test is that set out by de Grandpre j in Committee for Justice and Liberty $v$ National Energy Board: ${ }^{104}$

... the apprehension of bias must be a reasonable one, held by reasonable and right-minded persons, applying themselves to the question and obtaining thereon the required information ... [T] hat test is 'what would an informed person, viewing the matter realistically and practically - having thought the matter through - conclude'. Would he think that it is more likely than not that [the decision-maker], whether consciously or unconsciously, would not decide fairly. The grounds for this apprehension must, however, be substantial and I ... refus[e] to accept the suggestion that the test be related to the 'very sensitive or scrupulous conscience'.

This test was adopted by the Supreme Court of Canada in $R v S(R D)$. In this case, a white police officer arrested a black 15-year-old who had allegedly interfered with the arrest of another youth. The accused was charged with unlawfully assaulting a police officer with the intention of preventing an arrest and unlawfully resisting a police officer in the lawful execution of his duty. The police officer and the accused were the only witnesses and their accounts of the relevant facts differed widely. The Youth court judge weighed the evidence and determined that the accused should be acquitted. While delivering her oral reasons, the judge remarked in response to a rhetorical question by the Crown, that police officers had been known to mislead the court in the past that they had been known to overreact particularly with non-white groups and that that would indicate a questionable state of mind. She also stated that her comments were not tied to the police officer testifying before the court. The Crown challenged these comments as raising a reasonable apprehension of bias. After the reasons had been given and after an appeal to the Nova Scotia Supreme Court (Trial Division) had been filed by the Crown, the judge issued supplementary reasons, which outlined in greater detail her impressions of the credibility of both witnesses and the context in which the comments were

104 Committee for Justice and Liberty v National Energy Board [1978] 1 SCR 369. Grandpré j wrote a dissenting opinion but his formulation was adopted by the majority and followed in subsequent cases such as Valente $v$ Queen [1985] 2 SCR 673; $R$ v Lippé [1991] 2 SCR 114; Ruffo v Conseil de la magistrature [1995] 4 SCR 267. 
made. The Crown's appeal was allowed and a new trial was ordered on the basis that the judge's remarks gave rise to a reasonable apprehension of bias. The judgment was by a majority of the Nova Scotia Court of Appeal. The appeal to the Supreme Court of Canada rested on the issue whether the judge's comments in her reasons gave rise to a reasonable apprehension of bias. The Supreme Court in a split decision (La Forest, L'Heureux-Dubé, Gonthier, Cory, McLachlin and lacobucc jj in the majority and Lamer CJ, Sophinka and Major jj dissenting) held that the remarks by the judge did not raise a reasonable apprehension of bias. Cory j whose formulation of the test was adopted by the majority further amplified the test for bias. He said:

This test has been adopted and applied for the past two decades. It contains a two-fold objective element: the person considering the alleged bias must be reasonable, and the apprehension of bias itself must also be reasonable in the circumstances of the case. Further the reasonable person must be an informed person, with knowledge of all relevant circumstances, including the traditions of integrity and impartiality that form a part of the background and apprised also of the fact that impartiality is one of the duties the judges swear to uphold...the reasonable person should also be taken to be aware of the social reality that forms the background to a particular case, such as societal awareness and acknowledgment of the prevalence of racism and gender bias in a particular community... a real likelihood or probability of bias must be demonstrated and... a mere suspicion is not enough. Regardless of the precise words used to describe the test, the object of the different formulations is to emphasize that the threshold for a finding of real or perceived bias is high. It is a finding that must be carefully considered since it calls into question an element of judicial integrity. The onus of demonstrating bias lies with the person who is alleging its existence. Further, whether a reasonable apprehension of bias arises will depend entirely on the facts of the case. ${ }^{105}$

Major $\mathrm{j}$ wrote the dissenting opinion and adopted the test elaborated by Denning mr in Metropolitan Properties:

[I]n considering whether there was a real likelihood of bias, the court does not look at the mind of the justice himself or at the mind of the chairman of the tribunal or whoever it may be, who sits in a judicial capacity. It does not look to see if there was a real likelihood that he 
would, or did, in fact favour one side at the expense of the other. The court looks at the impression which would be given to other people. Even if he was as impartial as could be, nevertheless if right minded person would think that, in the circumstances, there was a real likelihood of bias on his part, then he should not sit ... 106

The split seen in the Canadian Supreme Court on the proper interpretation of the reasonable apprehension test is, as is seen to be present and not surprisingly in the South African Constitutional Court as evident in SACCAWU 1.

In Australia, the case of Livesey $v$ New South Wales Bar Association ${ }^{107}$ represented a new ${ }^{108}$ and different approach in the tests for judicial bias. The court held that:

... [a] judge should not sit to hear a case if in all the circumstances the parties or the public might entertain a reasonable apprehension that he might not bring an impartial and unprejudiced mind to the resolution of the question involved in it. ${ }^{109}$

In Webb $v$ Queen ${ }^{110}$ the High Court of Australia was asked to reconsider its approach in Livesey and Watson in the light of the decision of the English House of Lords in Gough. It declined to do so. In Johnson v Johnson ${ }^{111}$ the High Court of Australia elaborated the reasonable apprehension test. In that case the court reached a unanimous decision on the facts there was a fundamental difference in the interpretation of the test consistent with our analysis of the position in South Africa and Canada. Glesson CJ, Gaudron, McHugh, Gummow and Hayne jj believed that the reasonable apprehension of bias test has been adopted:

$106 \mathrm{~N} 32$ at 599.

107 N 79.

108 See the cases of Dickason v Edwards (1910) 10 CLR 243; $R$ v Australian Stevedoring Industry Board; Ex parte Melbourne Stevedoring Co Pty Ltd (1953) 88 CLR 100.

109 N 79 at 293-294. See also R v Watson; Ex parte Armstrong (1976) 136 CLR 248 (hereafter Watson); Australian National Industries Ltd v Spedley Securities Ltd (in Liq) (1992) 26 NSWLR 411.

110 Webb v Queen (1994) 181 CLR 41.

111 Johnson $v$ Johnson [2000] HCA 48 (hereafter Johnson). 
[f]or the reason that it gives due recognition to the fundamental principle that justice must both be done, and be seen to be done. It is based upon the need for public confidence in the administration of justice...the hypothetical reasonable observer of the judge's observer of the judge's conduct is postulated in order to emphasise that the test is objective, is founded in the need for public confidence in the judiciary, and is not based purely upon the assessment by some judges of the capacity and performance of their colleagues. At the same time, two things need to be remembered: the observer is taken to be reasonable; and the person being observed is a professional judge whose training, tradition and oath of affirmation require [the judge] to discard the irrelevant, the immaterial and the prejudicial. Whilst the fictional observer, by reference to whom the test is formulated, is not to be assumed to have a detailed knowledge of the law, or of the character or ability of the particular judge, the reasonableness of any suggested apprehension of bias is to be considered in the context of ordinary judicial practice. ${ }^{112}$

Kirby j proffered a different interpretation by focusing on the knowledge to be imputed to the reasonable observer as being determinative. In his opinion:

The test which the law calls for interposes a fictitious bystander. It hypothesizes a person whose judgment in the matter is taken to be determinative. One might consider that the fiction should not be taken too far ... the interposition of the fictitious bystander and the adoption of a criterion of disqualification expressed in terms of possibilities rather than "high probability" are both intended to serve an important social interest...Each of these considerations lays emphasis on the need to consider the complaint made ultimately, not by what adjudicators and lawyers know, but by how matters might reasonably appear to the parties and the public. That is why one does not attribute to the fictitious bystander highly specialized knowledge, such as that known perhaps to only some lawyers concerning the supposed inclinations and capacities of a particular adjudicator. It is also why it would be a mistake for a court simply to impute all that was eventually known to the court to an imaginary reasonable person because to do so would be only to hold up a mirror to itself. ${ }^{113}$

Kirby $\mathrm{j}$ highlighted the possibility that the fictitious bystander may be a throwback to the real danger test in Gough. He said:

Does the law assume that the bystander is simply a member of the public who may have sat in the back of the court room and heard no 
more than the particular statement of the primary judge about which the appellant complains? Most members of the public, if they visit the courts at all, stay only for matter of minutes, rarely for hours, and almost never for days. Even parties, if represented, may absent themselves entirely or for extended periods of time. Does the law presume that, to make the hypothesized decision, given its serious consequences the fictitious bystander will secure acquaintance with at least the five considerations mentioned above. ${ }^{114}$ If such knowledge is to be attributed to the bystander, does that fact undermine the modern test adopted by this court and restore once again the restrictive judgment according to the opinion of lawyers rather than the public? Would that be effectively to shift the balance back to the test ... at least towards the "real danger" test adopted by the House of Lords in Gough despite its recent rejection by this Court in Webb? ${ }^{115}$

It is remarkable that in subsequent cases, the High Court of Australia has become polarized along these lines with Kirby j dissenting from the majority of the court in holding that the correct interpretation of the reasonable apprehension test is the apprehension of the public, while the majority of the court imputes the reasonable man with the court's knowledge of the facts. ${ }^{116}$ The analysis above indicates quite clearly that the threshold of judicial bias is high in Canada and accordingly, is high in South Africa. The illuminating analysis of Kirby $\mathrm{j}$ in Johnson supports the contention that the interpretation of the reasonable apprehension test in SARFU 2 makes the test similar to the real danger/likelihood of bias test in Gough. This similarity lies in the high threshold.

\section{Concluding remarks}

114 These considerations are listed in par 46 ibid and can be summarised as follows: (1) Appellate judges realise that most judges strive to be independent and impartial and to make adjustments for factors of which they are aware might affect their decision. (2) A judge need not be silent in the course of the proceedings and a frank dialogue may serve the interests of justice. (3) Preliminary inclinations by judicial officers do change. (4) The adversary system depends on a vigorous interaction not only between the parties and their representatives but also between the judge and other persons. (5) Unlike before when judges discerned the truth based on their impressions of witnesses, now their decisions are based on indisputable facts, contemporary documents and logic of the circumstances.

115 Ibid par 50.

116 See Hot Holdings Pty Ltd v Creasy [2002] HCA 51. 
The interpretation of the manifest justice principle as the context for the application of the tests for recusal will lower the threshold of bias, thereby allowing more application for recusal to succeed. For the administration of justice, this is of considerable importance. It means that where a case is on the borderline, it should be resolved in favour of recusal. The difficulty that the test in SARFU 2 presents is that since the threshold is high, it is unlikely that a presiding officer being asked to recuse himself will invariably apply the objective legal value and rule that because of his training, such facts as alleged as leading to an apprehension of bias have indeed not affected him. For example, it is arguable that applying the SARFU 2 test, the judge and the appellate court in Moch would have ruled that the strenuous efforts made by the judge a quo were aimed at establishing an objective legal value which the applicant for recusal had not rebutted, especially as the applicant was depending on information received on an alleged strained relationship between the judge and her counsel. Accordingly, it is submitted that the Constitutional Court of South Africa should adopt the interpretation of the minority in SACCAWU 1 to enable the manifest justice principle to be applied. It is further submitted that the emergence of South Africa from the apartheid era demands such a low threshold to build public confidence. The choice of Canadian jurisprudence in this regard is with due respect wrong. As seen, it flew in the face of established local jurisprudence and has put South Africa in a position similar to the English position in Gough, which the English have moved from and from which the Appellate Division in BTR Industries and the world refused to follow.

This advocacy of the manifest justice principle hinges on the fact that the minority view of the reasonable apprehension test similar to the reasonable suspicion test is also capable of so much manipulation as it is very easy to determine what a reasonable person should think, especially when it is the court that personifies that reasonable person. It is the principle that will ensure that such manipulations do not become common-place. The principle enables the reasonable man to be fit into the place of the lay litigant without knowledge of judicial traditions and practice. In other words, the present objective nature of the reasonable suspicion test would be infused with a considerable amount 
of the subjective elements that the lay litigant would personify. Applying the manifest justice principle recognises the fact that applications for recusal should not be perceived by the judicial officers to be a personal affront and an indictment of their integrity. This is a point that is trite yet has not been influential. The need for public confidence demands that judicial officers swallow their ego and put the system above their personal sentiments.

In applying the manifest justice principle, there is the increased possibility that litigants may use it for judge-shopping. It is acknowledged that this is a veritable criticism of the manifest justice principle as one cannot rule out frivolous attacks on judicial officers for the purposes of judge-shopping or embarrassment. In any case, it is implicit in the manifest justice principle that it is advocated that frivolous and embarrassing attacks on the judiciary will have no place. Even the constructed lay litigant should be able to discern such cases and enable courts to dismiss such applications.

There is no doubt that a low threshold will exact a considerable cost on the judiciary. However any price is worth paying for this confidence. In this regard the opinion of Lord Bruckmaster in Sellar $v$ Highland R/y ${ }^{117}$ approved in Pinochet $2^{118}$ is apposite:

The law remains unaltered and unvarying to-day, and although it is obvious that the extended growth of personal property and the wide distribution of interests in vast commercial concerns may render the application of the rule irksome, it is nonetheless a rule which I for my part should greatly regret to see even in the slightest degree relaxed. The importance of preserving the administration of justice from anything which can even by remote imagination infer a bias or interest in the Judge upon whom falls the solemn duty of interpreting the law is so grave that any small inconvenience experienced in its preservation may be cheerfully endured.

It is hoped that the South African Constitutional Court would, as the English House of Lords has indicated in Lawal, at the earliest opportunity, move decisively to lower the threshold of judicial bias. In doing this it will give real 
and substantive meaning to the constitutional injunctions requiring impartial adjudication of disputes.

118 N 7 p 593. 


\section{Bibliography}

Baxter Administrative Law

Baxter L Administrative Law (Juta Cape Town1984)

Devenish 2000 TSAR 397

Devenish G "Disqualifying bias: the second principle of natural justice the rule against partiality or bias (nemo iudex in propria causa)" 2000 TSAR 397

Malleson 2000 Modern Law Review 119

Malleson K "Judicial bias and disqualification after Pinochet No. 2" 2000 (63) Modern Law Review 119

Okpaluba 2003 JJS 109

Okpaluba C "Institutional independence and the constitutionality of legislation establishing lower courts and tribunals: Part 1" 2003 (28) JJS 109

Okpaluba 2004 TLR 1

Okpaluba C "Independence and impartiality as twin-pillars of the right to fair hearing: a review of Sole $v$ Cullinan and Others" 2004 (1) TLR 1

Hoexter, Lyster and Currie Constitutional and Administrative Law 192 Hoexter C, Lyster R and Currie I The New Constitutional and Administrative Law. Volume 2: Administrative Law (Juta Cape Town 2002)

\section{Register of Cases}

Auckland Casino Ltd v Casino Control Authority [1995] 1 NZLR 142

Australian National Industries Ltd v Spedley Securities Ltd (in Liq) (1992) 26 NSWLR 411

Bam-Mugwanya $v$ Minister of Finance and Provincial Expenditure, Eastern Cape 2001 (4) SA 120 (Ck)

Bradford v McLeod 1986 SLT 244

BTR Industries South Africa (Pty) Ltd V Metal and Allied Workers Union 1992 (3) SA 673 (A)

Committee for Justice and Liberty $v$ National Energy Board [1978] 1 SCR 369 
Council of Review, South African Defence Force $v$ Monning and Others 1992

(3) SA 482 (A)

De Cubber v Belgium (1984) 7 EHRR 236

De Lille v Speaker of the National Assembly; 1998 (3) SA 340 (C)

Dickason v Edwards (1910) 10 CLR 243

Dimes v Proprietors of the Grand Junction Canal (1852) 3 HL Case 759

Ebner v Official Trustee in Bankruptcy (2000) 205 CLR 337

Ebner v The Official Trustee in Bankruptcy [2000] HCA 63

Findlay v UK 199724 EHRR 221

Hautschildt v Denmark (1989) 12 EHRR 266

Hot Holdings Pty Ltd v Creasy [2002] HCA 51

Ighayiya Technical College v Member of the Executive Council for Education, Eastern Cape 1998 (4) SA 502 (Ck)

In re Medicaments and Related Classes of Goods (No. 2) [2001] 1 WLR 700

Johnson v Johnson [2000] HCA 48

Lawal v Northern Spirit Ltd [2004] 1 All ER 187

Liebenberg v Brakpan Liquor Licensing Board 1944 WLD 52

Livesey v New South Wales Bar Association (1983) 151 CLR 288

Locabail (UK) Ltd v Bayfield Properties Ltd, Locabail (UK) Ltd v Waldorf Investment Corp, Timmins v Gromley, Willams v HM Inspector of Taxes, $R v$ Bristol Betting and Gaming Licensing Committee, ex parte O'Callaghan [2000] 1 All ER 65 (CA)

Mackin v New Brunswick (Minister of Justice); Rice v New Brunswick (2002) $209 \operatorname{DLR}\left(4^{\text {th }}\right) 564$

Magqabi v Mafundityala (1979) 4 SA 106 (E)

Metropolitan Properties Co (FGC) Ltd v Lannon [1969] 1 QB 577

Millar v Dickson 2001 SLT 988

Minister of Justice $v$ Sapire (civ App 49/2001, 10.6.02 unrep)

Moch v Nedtravel (Pty) Ltd t/a American Express Travel Service 1996 (3) SA $1(A)$

Parag v Ladysmith City Council 1961 (3) SA 714 (A)

Peri-Urban Areas Health Board v Administrator Transvaal 1961 (3) SA 669 (T)

Piersack v Belgium (1982) 5 EHRR 169

Porter v Magill [2001] 1 All ER 465 (HL)

President of the Republic of South Africa $v$ South Africa Rugby Football Union (2) 1999 (4) SA 147

Pullar v UK (1996) 22 EHRR 391 
$R$ v Australian Stevedoring Industry Board; Ex parte Melbourne Stevedoring Co Pty Ltd (1953) 88 CLR 100

$R$ v Barnsley County Borough Licensing Justices, ex parte Barnsley and District Licensed Victuallers' Association [1960] 2 QB 167

$R$ v Bow Street Metropolitan Stipendiary Magistrate and others ex parte Pinochet Ungarte (No. 2) [1999] All ER 577

$R$ v Box [1964] 1 QB 340

$R v$ Bristol Betting and Gaming Licensing Committee, ex parte O'Callaghan [2000] QB 451

$R$ v Camborne Justices ex parte Pearce [1954] 2 All ER 850

$R$ v Gough [1993] 2 All ER 724 (HL)

$R v$ Inner West London Coroner, ex parte Dallaglio [1994] 4 All ER 139

$R$ v Lippé [1991] 2 SCR 114

$R$ v Liverpool City Justices, ex parte Topping [1983] 1 All ER 490

$R v$ Mulvihill [1990] 1 All ER 436

$R v$ Rand (1866) LR 1 QB 230

$R$ v Roberts 1999 (4) SA 915 (SCA)

$R$ v Sawyer (1980) 71 Cr App R 283

$R v$ Secretary of State for the Home Department ex parte Daly [2001] 3 All ER $433(\mathrm{HL})$

$R v$ Silber 1952 (2) SA 475

$R \vee$ Somciza 1990 (1) SA 361 (A)

$R$ v Spencer [1987] AC 128

$R$ v Sussex Justices, ex parte McCarthy [1924] 1 KB 256

$R$ v Sussex Justices, ex parte McCarthy [1923] All ER 233

$R \vee T 1953$ (2) SA 479 (A)

$R$ v Watson; Ex parte Armstrong (1976) 136 CLR 248

$R$ v S (RD) (1997) 118 CCC (3d) 353

Rose $v$ Johannesburg Local Road Transportation Board 1947 (4) SA 272 (W)

Ruffo $v$ Conseil de la magistrature [1995] 4 SCR 267

S v Bam 1972 (4) SA 41 (SE)

$S v$ Collier 1995 (8) BCLR 975 (C)

$S v$ Herbst 1980 (3) SA 1026 (T)

$S$ v Louw, S v Noyila 1981 (4) SA 939 (E)

$S$ v Malindi 1990 (1) SA 962 (A)

S v Radebe 1973 (1) SA 796 (A)

$S$ v Sharp [2002] JOL 9320 (Ck) 
SACCAWU v President, Industrial Tribunal 2001 (2) SA 277 (CC)

SACCAWU v Irvin \& Johnson Ltd (Seafoods Division Fish Processing) 2000

(3) SA 705 (CC)

Sager v Smith 2001 (3) SA 1004 (SCA)

Sekoati and Others $v$ President of the Court Martial and Others 2001 (7)

BCLR 750 (Les CA)

Sellar v Highland Rly Co 1919 SC (HL)

Shackell v S [2001] 4 All SA 279 (A)

Silwana v Magistrate for the District of Piketberg [2003] 3 All SA 350 (C)

Sole v Cullinan NO and others [2003] 3 All SA 466 (Les CA).

Take and Save Trading CC v Standard Bank of SA Limited 2004 (4) SA 1 (SCA)

Taylor v Lawrence [2002] 2 All ER 353

Timmins v Gormley (2000) 2 WLR 870

Valente v Queen [1985] 2 SCR 673

Webb v R (1994) 181 CLR 41

Webb v Queen (1994) 181 CLR 41

Wildlife Society of Southern Africa $v$ Minister of Environmental Affairs and Tourism of the Republic of South Africa [1996] 3 All SA 462 (Tk).

\section{Register of Legislation}

Constitution of the Republic of South Africa 108 of 1996

European Convention of Human Rights and Fundamental Freedoms of 2000 